\title{
Representation of Gender in South African Television Advertising: A Content Analysis
}

Russell Luyt 
Abstract This paper examines how gender is represented in South African television advertising. It provides a foundation upon which changes in representation over time may be mapped; contributes toward a cross-national literature that considers differences in representation; and tentatively examines how representations intersect with other key social categories. A sample of 5,803 advertise- ments was collected during 2003 that included 1,633 primary visual actors and 2,350 narrators. These were analysed by means of content analysis. A coding scheme was developed that was partly based on existing research, including McArthur and Resko's (1975) influential study, but also research within non-Western contexts. Content categories included attributes of the primary visual actor (i.e., age; portrayal; race; and social class) as well as advertisement attributes (i.e., actors; primary narrator; products; and setting). Hypotheses predicted that males and females would be represented differently in television advertisements and that these differences would reflect traditional hierarchical relations in society. Findings largely supported these hypotheses. Males were represented as dominant. They were of primary focus; appeared most frequently within the socially valued public-work arena; and were represented as occupying positions of greater social authority. Females were represented as subordinate. They were of secondary focus; appeared most frequently within the socially undervalued private-domestic arena; and were most often represented as occupying positions of social subordination. This subordination was reinforced through findings that imply their sexualisation. Interesting patterns also emerged in findings indicating possible change in representations of gender. The implications of findings are discussed and suggestions for future research are made.

Keywords Gender representation · Gender role portrayal · South Africa · Television advertising 


\section{Introduction}

This paper examines how gender is represented in South African (SA) television advertising through content analysis. Existing content analytic work tends to focus on Western (e.g., Bresnahan et al. 2001, n=131, United States; Furnham and Bitar 1993, $\mathrm{n}=180$, United Kingdom) and Asian nations (e.g., Kim and Lowry 2005, n=878, Korea; Uray and Burnaz 2003, $n=314$, Turkey). The few studies that examine gender representation in SA television advertising (e.g., Furnham and Spencer-Bowdage 2002, $n=77$; Milner 2005, n=55) suffer from small or unrepre- sentative samples. Moreover, only limited research con- siders how gender representations in media intersect with other social categories such as race (e.g., Coltrane and Messineo 2000, n=1,699, United States) and social class (e.g., Glascock and Ruggiero 2004, $n=284$, United States). This study seeks to remedy these weaknesses. It aims to provide a firm foundation, with data from 2003, upon which future research might map changes in SA representa- tions over time; contribute toward a cross-national literature that considers differences in representation; and tentatively examine how representations intersect with other key social categories in SA such as race and social class. Social constructionism provides the theoretical framework for this endeavour (see Burr 2003; Gergen 1999). 
The use of social categories in research, including those of race and gender, has stimulated much debate. Concern surrounds the extent to which research contributes toward the reification of social categories and thereby helps to maintain axes of inequality in society. This study makes use of social categories. However, these are understood as social constructs, and not essential to individuals. Their use is justified though the "social and analytical weight” (Morrell 2001, p. ix) they offer. Category descriptors reflect their current construction in South African society. For example, in the case of race, these include Asian; Black African; Coloured; and White.

SA offers a particularly interesting case through which to examine gender representation in television advertising. Social relations have traditionally been characterised by acute inequalities (Seekings and Nattrass 2006). The country is perhaps best known for race-based inequalities that emerged, and were sustained through, White minority rule over the colonial and neo-colonial Apartheid era (Terreblanche 2003). Yet emphasis on race issues in SA may at times have served to obscure quite profound gender inequalities (Oyegun 1998). This is evident through measures such as the Gender-Related Development Index (GDI) that ranks the country $109^{\text {th }}$ in terms of worldwide gender equalitarianism (United Nations Development Programme 2009). It is also apparent in literature bearing witness to the dominance of traditional gender attitudes (Kalichman et al. 2005; Luyt 2005) and discourses (Luyt

2003; Reddy and Dunne 2007).

Gender inequality is therefore an evident feature of SA society. But it is important to note that relatively recent sociopolitical change, exemplified by democratic elections in 1994, has served to challenge the status quo (Morrell

2002). Growing critical awareness of gender issues is arguably one such site of challenge (Morrell 1998). Connell (2000, p. 14) notes that "a conscious reconstruction of gender practices is now on the agenda in southern Africa". Current gender debate extends beyond academia and is also apparent in the political and civil arena (Morrell 1998).

Legislative efforts have featured prominently at the vanguard of gender reconstruction in post-Apartheid SA (Levett and Kottler 1998). The SA transitional Constitution of 1993 [Section 8(1) and 8(2)] ushered in the apparent possibility for dramatic transformation. This provided for equality before the law, irrespective of, among other things race, gender and sexual orientation. Similar provisions were adopted in the SA Constitution of 1996 [Section 9(3)]. Such debates are also evident in civil society. Transforma- tion is clearly seen in, for example, the lively negotiation of gay masculinity (Reddy 1998); the active debate concerning gender roles and relations of power between men and women (Shefer et al. 2008); and discussions regarding the obligations and rights of natural fathers and childcare (de Villiers 1998). Examining gender representa- tion in television advertising is a worthwhile pursuit in a country characterised by traditional gender relations and inequality but undergoing dramatic socio-political challenge and change.

The gender role perspective has dominated empirical mass communication research (Fejes 1992; Hanke 1992). Studies frequently attempt to describe and/or determine the effect of stereotypical gender role portrayal through the analysis of manifest media content. Research concerning gender role portrayal, specifically in television advertising, took steady hold during the early 1970s (Uray and Burnaz

2003; Furnham et al. 2000). Much of this has been conducted in the United States (Arima 2003). Findings overwhelmingly confirm that male and female gender roles are portrayed through the use of traditional stereotypes in television advertising (Arima 2003; Bresnahan et al. 2001; Livingstone and Green 1986). These advertisements exag- gerate the extent to which men and women's behaviour actually differs, through relying on gender stereotypes (Furnham and Spencer-Bowdage 2002), and have report- edly been encouraged through industry preference for gender-product marketing strategies (Fejes 1992).

Dominick and Rauch (1972, n=235, United States) and McArthur and Resko (1975, n=199, United States) were among the first to explore gender role portrayal in television advertising. These studies have proven highly influential. Their coding schemes have served to guide subsequent research surrounding this topic. This has resulted in a fair degree of measurement standardisation (Furnham and Mak 1999; Furnham et al. 2000; Furnham and Spencer-Bowdage 2002) and has led to greater confidence in findings. Studies have consistently demon- strated significant gender differences in the portrayal of primary visual actors (Furnham and Spencer-Bowdage

2002). Coding units commonly used in these studies have similarly been included in this paper [i.e., actors (e.g., Furnham and Bitar 1993; Kim and Lowry 2005); age (e.g., Furnham and Skae 1997, n=162, United Kingdom; Furnham and Chan 2003, n=154, Hong Kong); narrator (e.g., Furnham et al. 1997, n=134, United States/United Kingdom; Lee 2004, $n=92$, Singapore); products (e.g., Furnham and Farragher 2000, n=351, New Zealand/ United Kingdom; Milner 2007, $n=55$, South Africa); race (e.g., Coltrane and Messineo 2000; Furnham and Spencer- Bowdage 2002); and setting (e.g., Furnham et al. 2000, n=294, Hong Kong/Indonesia; Milner 2005)]. 
Furnham and Spencer-Bowdage (2002) have conducted one of the few studies undertaken in Africa. The authors compared gender role stereotyping in a sample of SA $(n=77)$ and British $(n=95)$ television advertisements. These were collected over the same time period and were limited to those aired during evening prime time. SA advertisements were drawn from SABC (South African Broadcast Corporation) channels 1, 2 and 3. British advertisements were restricted to Channel 5. Content analysis was undertaken. Findings indicated that traditional gender role stereotyping occurred less in British advertisements than was found in previous years; that the SA advertisements displayed a greater tendency towards traditional gender role stereotyping than the British advertisements; and that traditional gender role stereotyping increased in the analysis of primary visual actors but decreased in the analysis of secondary visual actors. The SA findings were said to reflect similar levels of traditional stereotyping found in earlier Western studies and recent studies from other non- Western countries. Milner (2005) likewise conducted a study in order to examine gender-role portrayal in African, including SA, television advertising.

Both of these studies suffer from methodological weak- nesses including small and unrepresentative sample sizes. Furnham and Spencer-Bowdage (2002) analyse a relatively restricted sample of 77 advertisements obtained from three public broadcasting channels. Advertisements from E-TV, a private free-to-air channel, were not sampled. The authors claim that "Channel 5, the newest terrestrial channel

available in England, was most closely matched to the SABC” (p. 463). Channel 5 is a private free-to-air channel and therefore should not be seen as analogous to the SABC as a public broadcaster. Milner's (2005) study similarly included a very small sample of advertisements $(\mathrm{n}=55)$ and provides no detailed information regarding sampling strategy.

Lastly, few studies have considered how gender repre- sentations in media intersect with other social constructs, such as race (Coltrane and Messineo 2000). Coltrane and Messineo (2000) provide an unusual example in two respects. Firstly, the authors describe how gender and race are constructed by television advertising, thus adopting a social constructionist as opposed to a gender role theoretical perspective, but also explore how these social constructs intersect. Secondly, they successfully make use of content analytic procedures, although this method of analysis is ordinarily favoured by research that adopts the gender role perspective. One thousand six hundred ninety-nine television advertisements were sampled from programmes targeted at theoretically important audiences in the United States. Findings suggest that in general White men were portrayed as powerful; White women as sex objects, domesticated, and romantically successful; Black men as aggressive; and Black women as inconsequential. These representations are argued to reinforce subtle prejudice against women in general and African Americans in particular.

The current study seeks to examine how gender is represented in SA television advertisements. It is assumed, in agreement with existing content analytic research conducted in SA (e.g., Furnham and Spencer-Bowdage 2002; Milner 2005), and other developing nations (e.g., Uray and Burnaz 2003), that media construct and represent gender in a fashion that maintains hierarchical gender relations. Theoretical emphasis is placed on the notion of

'gender representation' as opposed to 'gender role portrayal'. This is more in keeping with a social constructionist understanding of gender (see Bohan 1993; West and Zimmerman 1991). In order to explore this phenomenon, it is useful to consider how masculinity and femininity are constructed, as well as outline how important social categories such as race and social class intersect with gender representation in television advertising. Content analysis provides a useful analytic method in this study in that it facilitates examination of the extent to which males and females are represented significantly differently in television advertisements so as to reflect traditional hierarchical relations in society. A number of hypotheses are examined. These are largely informed by existing research and assume "( $\mathrm{t}$ )he worth of characters... is symbolically commu- nicated by their absence or abundance on screen and by the quality of their portrayals" (Lauzen and Dozier 2005, p. 438). We are therefore interested in both whether males and females are represented as well as how (Collins 2011).

A number of reviews concerning content analyses of gender representation in media (e.g., Collins 2011) and television advertising (e.g., Eisend 2010; Furnham and Mak

1999; Furnham and Paltzer 2010) are available. These

review over two decades of research and helpfully summarise what is already known cross-nationally about many of the hypotheses examined in this paper:

H1: Males will be represented as primary visual actors significantly more frequently than females. This first hypothesis is informed by research indicating females are underrepresented as primary actors across differ- ent media. The consistency of this finding is especially interesting given that female participation in formal employment and the number of commercial television channels aimed at this audience has generally increased over time. Advertising targeted at females appears not to have kept pace with these changes (Collins 2011). 
H2: Males will be represented as primary narrators significantly more frequently than females. Findings relevant to this hypothesis mirror those above. Males are consistently more likely to appear as primary narrators or voice-overs than females (Furnham and Mak 1999; Furnham and Paltzer 2010). Both H1 and H2 assess the extent to which females are underrep- resented in contrast to males in television advertising. This underrepresentation may be considered to reflect their continued devaluation in society (van Zoonen 1994) or, as Gill (2007) suggests, reinforce men's greater authority.

H3: Males will be represented significantly more frequently in settings away from home, and less frequently in home settings, than females. This third hypothesis considers the degree to which females and males are repre- sented as inhabiting stereotypical gendered locations or settings. Existing research indicates that females are most frequently associated with home settings (Furnham and Paltzer 2010) whereas males are more frequently represented in a range of locations or settings outside of the home, including, for example, outdoors and at leisure (Furnham and Mak 1999; Furnham and Paltzer 2010). Change in these stereo- typical representations has reportedly taken place over the last few decades. Females have increasingly been represented outside of the home (van Zoonen

1994) whilst males have been represented more often with domestic settings (Gauntlett 2009). Yet these counterstereotypical representations remain limited.

H4: Male adults will be represented less frequently as alone with children than female adults. Similar to those findings relating to location or setting, existing research reveals that adult females are more frequently represented with children than adult males (Furnham and Mak 1999; Furnham and Paltzer 2010). This serves to reinforce their stereotypical representation as primary caregivers (Collins 2011) and men's absence from the domestic arena.

H5: Males will be associated significantly more frequently with masculine products such as vehicles, and less frequently with feminine products such as domestic goods, than females. This fifth hypothesis also exam- ines the extent to which males and females are stereotypically represented through their association with products. Whilst there is some crossnational variation in male and female association with food products, females tend to be coupled with body- and domesticrelated products, whereas males tend to be coupled with car-, sport-, and alcohol-related products (Furnham and Mak 1999; Furnham and Paltzer 2010).

H6: Males will be represented significantly more frequently within older adult age groups, and less frequently within younger adult age groups, than females. Available research indicates that females are represented as younger than males (Furnham and Paltzer 2010), where females are generally young and males' middle-aged (Furnham and Mak 1999). It is suggested that this encourages the sexualisation of females but promotes male authority (Gill 2007).

Whilst most variables examined by these hypotheses are standard to content analyses of television advertising, as supported in the discussion above, the variables examined in H7 (i.e., social class), H8 (i.e., race), and H9 (i.e., portrayal) are either not often researched or novel to this study. They therefore extend existing literature. H7 and H8 were informed by literature suggesting the pivotal intersection of gender, race, and social class as co-constructed and intersecting axes of inequality in SA (Gaitskell et al. 2010; Pelak 2005). The variable of 'portrayal' was considered a useful coding category in assessing overall evaluative representations of male and female primary visual actors. Collins (2011) supports examining positive portrayals of females in particular. Yet it is noted that defining positive (and negative) portrayal is a difficult task. These three hypoth- eses are lists below:

H7: Males will be represented significantly more frequently as of higher social class status, and less frequently as of lower social class, than females.

H8: Males will be represented significantly more frequently as members of the White population group, and less frequently as members of the Black population group, than females.

H9: Males will be portrayed significantly more positively and less negatively than females.

\section{Method}

Sample

It has long been argued that analysis of television advertise- ments is important given their ubiquity in society and useful in that they represent a manageable sampling unit (McArthur and Resko 1975). Available population statistics (Statistics South 
Africa 2003) support the notion that media are likely to play a central role in contributing toward gender representation within SA. Most households have access to some form of media. Yet access differs by media type. Radio is available in the largest percentage of households averaged across population group (i.e., 73\%). In contrast television is available in far fewer households (i.e., 53.8\%). This disparity may be explained as a result of variation across population group. $94.7 \%$ of White headed households have access to television. A high proportion of Asian (i.e., 91\%) and Coloured (i.e., 75.3\%) headed households also possess television. The comparatively low average percentage of households that have access to this media type may be explained as a result of the relatively low proportion of Black African headed households that possess televisions (i.e., 44.2\%). It may therefore be argued that radio data is most appropriate in exploration surround- ing media representations of gender in SA. However similarexisting studies elsewhere in the world favour the use of television data, and in particular, advertisements. It is also likely that socio-economic development will result in increased access to television across all population groups over time.

The current study makes use of television data. This enables it to draw upon, as well as contribute toward, a larger literature than would otherwise be possible through the use of radio data. Television advertisements are especially useful. They are easily accessible and their appearance on nationwide free-to-air channels reaches a wider audience than most regionally based radio content. The use of print media data is not suitable for the purposes of this study, as many people have limited access to this type of media, due either to financial constraints or illiteracy.

Television advertisements therefore served as the sampling unit in this study. They were recorded from all free-to-air channels available in the country. These included SABC 1,2 ,

3 and E-TV. Data collection took place over a 4 week period

from the 20th February to the 19th March 2003. A stratified sampling procedure was adopted through the use of a method known as the constructed or artificial week (Bauer 2000; Riffe et al. 1998). This method involved developing a sampling frame that stratified every day, over a specified period, into

8 day parts or time periods. These were each $3 \mathrm{hr}$ in length. The inclusion of day part in sampling procedure was considered especially important in this study. Research indicates that this mediates the representation of males and females in television advertisements (e.g., Craig 1992a). Random selection, without replacement of day parts, then took place. This continued until each day part under a specific day of the week had been selected. A number of day parts were re-sampled over a week period from the 10th March to the 16th March 2003. This was due to either signal or equipment failure.

A total of 5,803 advertisements were recorded of which

1,414 were unique. The repeat of unique advertisements ranged from 1 (6.85\%) to $36(.02 \%)$ and averaged 4.24 . These were edited under channel, as well as day of the week, and then catalogued. There is some debate in the literature as to whether repeated advertisements should be included in analysis (see Craig 1992a; Ganahl et al.

2003; Moon and Chan 2002). This study agrees with Ganahl et al. (2003, p. 547) who argue in accord with cultivation theory (Gerbner and Gross 1976) that repeated advertisements should be "coded because the process accurately exemplifies cultural cultivation via repetitive images". Channel self-promotional advertisements and competitions were, however, excluded. Two thousand eight hundred eighty-five were ultimately included in the analysis. Of these 1,633 contained primary visual actors and 2,350 included narrators.

Coding Scheme

A coding scheme was developed which was partly based on existing research that explored the portrayal of males and females in television advertising. Among others, this included McArthur and Resko's (1975) influential study. An effort was also made to consult research undertaken within Western (e.g., Ganahl et al. 2003, n=1,337, United States; Livingstone and Green 1986, $n=175$, United Kingdom) as well as non-Western (e.g., Arima 2003, n=531, Japan; Uray and Burnaz 2003) contexts. The categories used within these content analyses were selec- tively included and modified to form the current coding scheme. The aims of this study and the peculiarities of its data guided this process. Furnham et al. (2000) note that commercial advertising takes place in unique social, economic and cultural contexts, and as such researchers may be required to modify well-known coding schemes before applying them. For example, as is mentioned above, McArthur and Resko (1975, p. 212) include a category known as "arguments given by the central figure”. The central figure was coded as providing a "scientific argument", "non-scientific argument" or "no argument" in support of the advertised product. This category was not included in the current study. That is to say, whilst a "scientific argument" may provide a useful indicator of an actor's authority in Western contexts, this arguably may not be the case in non-Western contexts. The dominance of scientific discourse in modern Western contexts is due to a range of socio-historical factors (Gunnarsson 1997) that do not 
apply neatly elsewhere. It is important to note that such modification complicates comparison of findings with existing or future research.

Thus the coding scheme in this study developed through an iterative inductive-deductive process (see Bauer 2000; Berg 1998; Joffe and Yardley 2003) and categories were therefore informed by data as well as existing empirical work and theory. This process of category development facilitates comparison against existing findings and also allows exploration into novel questions (Joffe and Yardley

2003). Furnham and Spencer-Bowdage (2002) note that many content analyses undertaken in order to explore the portrayal of men and women in television advertising have devised categories that were not included in McArthur and Resko's (1975) study. Well-known coding schemes often only include categories that assess manifest content as opposed to latent content. It is currently fashionable to include an analysis of both (Berg 1998). This is congruent with an interpretive understanding of content analysis. It is for this reason that recent studies have tended to develop new and original categories rather than merely relying on those produced by studies such as McArthur and Resko's (1975) Content analyses often use more than a single coding unit (Berg 1998). For example, Moon and Chan (2002) devel- oped categories that assessed features of (a) the individual advertisement, and (b) the primary visual actors within each advertisement. These coding units were similarly included in this study. These are briefly described below.

\section{General Advertisement Attributes}

A number of advertisement attributes (i.e., channel; date; day part; language; and week part) were coded but were not considered central to the current analysis. They are therefore not reported under the results.

\section{Primary Narrator}

This is also often described as the 'voice-over' (e.g., Bresnahan et al. 2001). It refers to the gender of the voice, not attributable to any on-screen actor, which was heard for the longest time [i.e., it included two categories and their associated sub- categories: no or yes (female; male; or unclear)]. Voices that were singing were not considered narrators.

\section{Setting}

This is also often described as the 'location’ (e.g., Furnham and Bitar 1993). It refers to the surroundings in which the actor(s) appeared [i.e., it included four categories and their associated sub-categories: away from home (business; outdoors; restaurant/bar; school; or other/unclear); outdoors at home; indoors at home (bathroom; kitchen; or other/unclear) or other/ unclear]. The setting was required to remain onscreen for no less than $50 \%$ of the advertisement's duration.

\section{Actors}

This is also often described as the 'background' (e.g., Furnham et al. 2000). It refers to the combined gender-age characteristics of the actors who appeared in the advertise- ment [i.e., it included eight categories: male adult(s); female adult(s); child(ren); female and male adults; male adult(s) with child(ren); female adult(s) with child(ren); female and male adults with child(ren); or none]. This excluded animation, and actors who appeared on secondary visuals within the advertisement, such as book covers and television screens.

\section{Product}

This refers to the product that was advertised [i.e., it included ten categories and their associated sub-categories vehicle and related; clothing; domestic goods (indoor or outdoor); electronic and related; food (everyday or luxury);

finance (formal or informal); leisure (alcohol; book, film, music and radio; travel; or sport); personal care (body/ beauty care or health care); services; security; or other]. 
The primary visual actor is defined as the person who appeared on the screen for the longest time. This person is also often described as the 'central figure' (e.g., Furnham and Spencer-Bowdage 2002). The primary visual actor was required to remain onscreen for no less than $5 \mathrm{~s}$, during which they could appear alone or with other actors, so long as he/she was of primary visual focus. Animation was excluded. Likewise body parts (e.g., hands) were excluded unless clearly belonging to an identifiable actor.

Gender

This refers to a set of qualities and behaviors ascribed to females or males in society (i.e., it included four categories: female; male; unclear; or none).

Age

This could be mentioned, known (as in the case of a celebrity), or determined through physical features such as the face; hair; posture; clothes etc. (i.e., it included eight categories: 0 to $10 ; 11$ to 20 ; 21 to 30 ; 31 to 40 ; 41 to 50 ;

51 to 60 ; 60 onwards; or none).

\section{Social Class}

This refers to an individual's relative social ranking due to social and economic factors. This could be mentioned, known (as in the case of a celebrity), or determined through characteristics such as education, occupation; dress; accent etc. (i.e., it included four categories: lower-/working-class; upper-/middle-class; unclear; or none).

Race

This is a social construct that groups individuals primarily on the basis of visible characteristics. This could be mentioned, known (as in the case of a celebrity), or determined through characteristics such as skin colour; traditional dress; accent etc. [i.e., it included four categories and their associated sub- categories: Black (Asian/Indian; Black African; Coloured or unclear); White; unclear; or none].

Portrayal

This refers to the way in which the primary visual actor was portrayed overall. That is to say, coders are required to judge whether the advertisement cast the actor in a favourable light (i.e., it included four categories: negative; positive; neutral; or none).

\section{Coding}

A nominal measurement level was adopted in this study. This prevented the use of parametric statistics but was theoretically appropriate. Coding values were recorded on a separate coding sheet. This provided a permanent record of the coding process and aided data entry (Riffe et al. 1998).

The reliability of the coding process in content analyses remains of central importance. A measure of reproducibility was calculated in this study (see Table 1). Reproducibility refers to inter-coder reliability and therefore the extent to which classification produces the same results among different coders.

The author acted as the first coder. A professional psychologist acted as the second coder. Both coders were South African and therefore familiar with the interpretative context. Coder training involved careful reading of, and discussion concerning the coding scheme, as well as a pilot study. The latter made use of an independent sample of approximately 20 television 
advertisements. Problems encountered during coder training were resolved either through discussion or revision of the coding scheme. In content analyses, a majority of studies make use of percentage agreement when determining reproducibility, whilst only a minority calculate Cohen's Kappa (DuRant et al. 1997). This is problematic. Measures, such as percentage agreement, are less stringent than those such as Cohen's Kappa (Bauer 2000). Cohen's Kappa was therefore calculated in this study. This was undertaken on four separate occasions. Repetition of this kind serves a useful function in content analysis. Instances of low reliability indicate where coding may be improved. This is achieved through further coder training and/or the revision of category definition (Bauer 2000; Joffe and Yardley 2003; Weber 1990).

Fifteen percent of coded advertisements were sampled at four roughly equal intervals during the coding process. In most cases the training and revision undertaken as a result of these calculations appear to have improved inter-coder reliability. Improvement was most marked after the first calculation. Bauer (2000) observes the difficulty often involved in deciding upon an acceptable level of inter- coder reliability. Once again this is due to the fact that some measures are more stringent than others. As a rule of thumb, reliability is considered very high at $>.90$; high at $>.80$; and acceptable between .66 and .79. The final total reliability measure across all variables ranged between $\kappa=1.00$ and $\kappa=.75$. Thus inter-coder reliability in this study.

Table 1 Measure of inter-coder agreement (Cohen's Kappa)

\begin{tabular}{|c|c|c|c|c|c|}
\hline $\begin{array}{l}\text { Vartable } \\
\text { number }\end{array}$ & Category & $\begin{array}{l}\text { Cohen's Kappa } \\
\text { measure } 1(\mathrm{n}=76)\end{array}$ & $\begin{array}{l}\text { Cohen's Kappa } \\
\text { measure } 2(\mathrm{n}=105)\end{array}$ & $\begin{array}{l}\text { Cohen's Kappa } \\
\text { measure } 3(n=143)\end{array}$ & $\begin{array}{l}\text { Cohen's Kappa final } \\
\text { measure }(\mathrm{n}=432)\end{array}$ \\
\hline v1. & $\begin{array}{l}\text { Gender of primary } \\
\text { visual actor }\end{array}$ & .65 & .91 & .88 & .86 \\
\hline v2. & Primary narrator (LOC) & .93 & .98 & .96 & .95 \\
\hline v2. & $\begin{array}{l}\text { Primary narrator } \\
\text { (HOC) }\end{array}$ & .91 & .97 & .92 & .93 \\
\hline v3. & Setting (LOC) & .71 & .79 & .81 & .80 \\
\hline v3. & Setting (HOC) & .77 & .82 & .86 & .83 \\
\hline $\mathrm{v} 4$. & Actors & .81 & .91 & .90 & .90 \\
\hline v5. & Products (LOC) & .91 & .96 & .94 & .93 \\
\hline v5. & Products (HOC) & .92 & .97 & .95 & .94 \\
\hline v6. & $\begin{array}{l}\text { Age of primary visual } \\
\text { actor (LOC) }\end{array}$ & .57 & .79 & .74 & .75 \\
\hline v6. & $\begin{array}{l}\text { Age of primary visual } \\
\text { actor (HOC) }\end{array}$ & .59 & .87 & .78 & .79 \\
\hline v7. & $\begin{array}{l}\text { Social class of primary } \\
\text { visual actor }\end{array}$ & .60 & .88 & .84 & .80 \\
\hline v8. & $\begin{array}{l}\text { Race of primary visual } \\
\text { actor (LOC) }\end{array}$ & .67 & .94 & .86 & .87 \\
\hline v8. & $\begin{array}{l}\text { Race of primary visual } \\
\text { actor (HOC) }\end{array}$ & .66 & .94 & .87 & .87 \\
\hline v9. & $\begin{array}{l}\text { Portrayal of primary } \\
\text { visual actor }\end{array}$ & .57 & .86 & .85 & \\
\hline
\end{tabular}


HOC higher order categories; LOC lower order categories may be considered as ranging between very high to acceptable.

Results

The results of the content analysis are summarised in two tables below. These are presented for both lower and higher order categories where appropriate (Table 2).

Primary Visual Actor

An overall significant chi-square emerged for primary visual actors; $\chi^{2}(1, \mathrm{n}=1,617)=32.86, \mathrm{p}<.001$. Males $(55.04 \%$, $\mathrm{n}=890$ ) were more likely to appear than females $(44.96 \%, n=727)$. H1 (i.e., Males will be represented as primary visual actors significantly more frequently than females) was therefore confirmed.

\section{Primary Narrator}

An overall significant chi-square was found for narrators; $\chi^{2}(1, n=2,339)=1251.90, p<.001$. Male voices $(75.89 \%, n=$ $1,775)$ were more likely to be observed than female voices $(24.11 \%, n=564)$. H2 (i.e., Males will be represented as primary narrators significantly more frequently than females) was as a result supported.

\section{Setting}

An overall significant chi-square emerged for setting; lower order categories $\chi^{2}(9, \mathrm{n}=1,617)=271.96, \mathrm{p}<.001$ and higher order categories $\chi^{2}(3, \mathrm{n}=1,617)=226.02, \mathrm{p}<.001$. Males appeared proportionally more often in settings away from home $(71.35 \%, n=635)$ and outdoors at home $(2.58 \%, n=23)$ than did females (36.59\%, $n=266$ and $1.65 \%, n=12$ respectively). In particular males often appeared in business settings $(20.67 \%, n=184)$ and outdoors away from home $(37.30 \%, n=332)$. In contrast females appeared proportion- ally more frequently in settings that were indoors at home $(22.97 \%, n=167)$ than did males $(14.16 \%, n=126)$. Females appeared especially frequently in the kitchen $(9.08 \%$, $n=66)$. Both females and males appeared in settings away from home more often than indoors at home. H3 (i.e., Males will be represented significantly more frequently in settings away from home, and less frequently in home settings, than females) was therefore confirmed.

Actors

Single female $(13.21 \%, \mathrm{n}=381)$ and male $(13.10 \%, \mathrm{n}=378)$ adults were depicted in roughly equal proportions and were more likely to appear than children $(2.18 \%, \mathrm{n}=63)$. They most often appeared together $(28.56 \%, \mathrm{n}=824)$ rather than together with children $(14.90 \%, n=430)$. Female adults appeared alone with children; $(4.54 \%, n=131)$ marginally more often than male adults (3.22\%, n=93). H4 (i.e., Male adults will be represented less frequently as alone with children than female adults) was as a result supported (Table 3).

\section{Products}

The chi-square statistic traditionally requires a minimum cell frequency of $\geq 5$ (Haberman 1988). It was therefore not possible to calculate it on this occasion. Females were proportionally more often associated with clothing (3.03\%, $\mathrm{n}=22)$; domestic goods $(14.03 \%, n=102)$; food $(21.60 \%, n=157)$ and personal care $(46.22 \%, n=336)$. In contrast males were proportionally more frequently associated with vehicles and related goods $(12.92 \%, n=115)$; electronic and related goods $(11.01 \%$, $n=98)$; finance $(11.69 \%, n=104)$; services $(7.42 \%, n=66)$ and leisure $(11.46 \%, n=102)$. H5 (i.e., Males will be associated significantly more frequently with masculine products such as vehicles, and less frequently with feminine products such as domestic goods, than females) was therefore tentatively confirmed. 
A significant overall difference emerged across age catego- ries; lower order categories $\chi^{2}(6, \mathrm{n}=1,616)=225.70, \mathrm{p}<$ .001 and higher order categories $\chi^{2}(3, n=1,616)=$

99.83, $\mathrm{p}<.0001$. Females appeared proportionally more often in younger adult age categories, such as 21 to 30 (81.13\%, $\mathrm{n}=589)$, as opposed to males $(46.29 \%, \mathrm{n}=412)$. In addition males appeared proportionally more frequently in middle to older adult age categories, such as 31 to $40(24.72 \%, n=220)$, as opposed to females $(8.82 \%, n=64)$. Both males and females appeared proportionally more often in younger than older age categories. H6 (i.e., Males will be represented significantly more frequently within older adult age groups, and less frequently within younger adult age groups, than females) was as a result supported.

\section{Social Class}

An overall significant chi square emerged for social class; $\chi^{2}(2, n=1,615)=26.91, p<.001$. Females were proportion- ally more often represented as of upper/middle social class $(93.66 \%, n=680)$, and proportionally less frequently repre- sented as of lower/working social class $(4.41 \%, \mathrm{n}=32)$, in comparison to males $(86.28 \%, \mathrm{n}=767$ and $7.09 \%, \mathrm{n}=63$ respectively). Both males and females were represented proportionally more frequently as of upper than lower/ working social class. H7 (i.e., Males will be represented

Table 2 Percentage and frequency of male and female primary visual actors described by attribute coding categories

\begin{tabular}{|c|c|c|c|c|c|c|c|c|}
\hline \multirow[t]{2}{*}{ Variable number } & \multirow[t]{2}{*}{ Category } & \multicolumn{2}{|l|}{ Female } & \multicolumn{2}{|l|}{ Male } & \multirow{2}{*}{$\begin{array}{l}\text { Pearson } \\
\text { Chi-square }\end{array}$} & \multirow[t]{2}{*}{ df } & \multirow[t]{2}{*}{$\mathrm{p}<$} \\
\hline & & Frequency & Percent & Frequency & Percent & & & \\
\hline \multirow[t]{2}{*}{ v1. } & Gender of primary visual actor & 1,617 & 100.00 & 1,617 & 100.00 & 32.86 & 1 & .001 \\
\hline & Yes & 727 & 44.96 & 890 & 55.04 & & & \\
\hline \multirow[t]{2}{*}{ v2. } & Primary narrator & 2,339 & 100.00 & 1,617 & 100.00 & 1251.90 & 1 & .001 \\
\hline & Yes & 564 & 24.11 & 1,775 & 75.89 & & & \\
\hline \multirow[t]{13}{*}{ v3. } & Setting (lower order categories) & 727 & 100.00 & 890 & 100.00 & 271.96 & 9 & .001 \\
\hline & Away from home & & & & & & & \\
\hline & Business & 93 & 12.79 & 184 & 20.67 & & & \\
\hline & Outdoors & 139 & 19.12 & 332 & 37.30 & & & \\
\hline & Restaurant/Bar & 17 & 2.34 & 15 & 1.69 & & & \\
\hline & School & 4 & .55 & 10 & 1.12 & & & \\
\hline & Other/Unclear & 13 & 1.79 & 94 & 10.56 & & & \\
\hline & Outdoors at home & 12 & 1.65 & 23 & 2.58 & & & \\
\hline & Indoors at home & & & & & & & \\
\hline & Bathroom & 26 & 3.58 & 13 & 1.46 & & & \\
\hline & Kitchen & 66 & 9.08 & 21 & 2.36 & & & \\
\hline & Other/Unclear & 75 & 10.32 & 92 & 10.34 & & & \\
\hline & Other/Unclear & 282 & 38.79 & 106 & 11.91 & & & \\
\hline \multirow[t]{5}{*}{ v3. } & Setting (higher order categories) & 727 & 100.00 & 890 & 100.00 & 226.02 & 3 & .001 \\
\hline & Away from home & 266 & 36.59 & 635 & 71.35 & & & \\
\hline & Outdoors at home & 12 & 1.65 & 23 & 2.58 & & & \\
\hline & Indoors at home & 167 & 22.97 & 126 & 14.16 & & & \\
\hline & Other/Unclear & 282 & 38.79 & 106 & 11.91 & & & \\
\hline \multirow[t]{5}{*}{ v5. } & Products (higher order categories) & 727 & 100.00 & 890 & 100.00 & Cell freq. $<1$ & & \\
\hline & Vehicle and related & 11 & 1.51 & 115 & 12.92 & & & \\
\hline & Clothing & 22 & 3.03 & 3 & .34 & & & \\
\hline & Domestic goods & 102 & 14.03 & 61 & 6.85 & & & \\
\hline & Electronic and related & 28 & 3.85 & 98 & 11.01 & & & \\
\hline
\end{tabular}




\begin{tabular}{|c|c|c|c|c|c|c|c|}
\hline Food & 157 & 21.60 & 169 & 18.99 & & & \\
\hline Finance & 2 & .28 & 104 & 11.69 & & & \\
\hline Leisure & 39 & 5.36 & 102 & 11.46 & & & \\
\hline Personal care & 336 & 46.22 & 158 & 17.75 & & & \\
\hline Services & 16 & 2.20 & 66 & 7.42 & & & \\
\hline Security & 0 & .00 & 6 & .67 & & & \\
\hline Other & 14 & 1.93 & 8 & .90 & & & \\
\hline Age of primary visual actor (lower order categories) & 726 & 100.00 & 890 & 100.00 & 225.70 & 6 & .001 \\
\hline 0 to 10 & 24 & 3.31 & 29 & 3.26 & & & \\
\hline 11 to 20 & 18 & 2.48 & 62 & 6.97 & & & \\
\hline 21 to 30 & 589 & 81.13 & 412 & 46.29 & & & \\
\hline 31 to 40 & 64 & 8.82 & 220 & 24.72 & & & \\
\hline 41 to 50 & 14 & 1.93 & 122 & 13.71 & & & \\
\hline 51 to 60 & 7 & .96 & 24 & 2.70 & & & \\
\hline 60 onwards & 10 & 1.38 & 21 & 2.36 & & & \\
\hline Age of primary visual actor (higher order categories) & 726 & 100.00 & 890 & 100.00 & 99.83 & 3 & .001 \\
\hline 0 to 20 & 42 & 5.79 & 91 & 10.22 & & & \\
\hline 21 to 40 & 653 & 89.94 & 632 & 71.01 & & & \\
\hline 41 to 60 & 21 & 2.89 & 146 & 16.40 & & & \\
\hline 60 onwards & 10 & 1.38 & 21 & 2.36 & & & \\
\hline
\end{tabular}


Table 2 (continued)

\begin{tabular}{|c|c|c|c|c|c|c|c|c|}
\hline \multirow[t]{2}{*}{ Variable number } & \multirow[t]{2}{*}{ Category } & \multicolumn{2}{|l|}{ Femate } & \multicolumn{2}{|l|}{ Mate } & \multirow{2}{*}{$\begin{array}{l}\text { Pearson } \\
\text { Chi-square }\end{array}$} & \multirow[t]{2}{*}{ df } & \multirow[t]{2}{*}{$\mathrm{p}<$} \\
\hline & & Frequency & Percent & Frequency & Percent & & & \\
\hline \multirow[t]{4}{*}{ v7. } & Social class of primary visual actor & 726 & 100.00 & 889 & 100.00 & \multirow[t]{4}{*}{26.91} & \multirow[t]{4}{*}{2} & \multirow[t]{4}{*}{.001} \\
\hline & Lower/Working & 32 & 4.41 & 63 & 7.09 & & & \\
\hline & Upper/Middle & 680 & 93.66 & 767 & 86.28 & & & \\
\hline & Unclear & 14 & 1.93 & 59 & 6.64 & & & \\
\hline \multirow[t]{8}{*}{ v8. } & Race of primary visual actor (lower order categories) & 726 & 100.00 & 889 & 100.00 & \multirow[t]{8}{*}{17.2} & \multirow[t]{8}{*}{5} & \multirow[t]{8}{*}{.01} \\
\hline & Black & & & & & & & \\
\hline & Asian/Indian & 17 & 2.34 & 31 & 3.49 & & & \\
\hline & Black Africans & 179 & 24.66 & 262 & 29.47 & & & \\
\hline & Coloured & 21 & 2.89 & 33 & 3.71 & & & \\
\hline & Unclear & 5 & .69 & 1 & .11 & & & \\
\hline & White & 501 & 69.01 & 549 & 61.75 & & & \\
\hline & Unclear & 3 & .41 & 13 & 1.46 & & & \\
\hline \multirow[t]{4}{*}{ v8. } & Race of primary visual actor (higher order categories) & 726 & 100.00 & 889 & 100.00 & \multirow[t]{4}{*}{12.20} & \multirow[t]{4}{*}{2} & \multirow[t]{4}{*}{.01} \\
\hline & Black & 222 & 30.58 & 327 & 36.78 & & & \\
\hline & White & 501 & 69.01 & 549 & 61.75 & & & \\
\hline & Unclear & 3 & .41 & 13 & 1.46 & & & \\
\hline \multirow[t]{4}{*}{ v9. } & Portrayal of primary visual actor & 718 & 100.00 & 890 & 100.00 & \multirow[t]{4}{*}{78.62} & \multirow[t]{4}{*}{2} & \multirow[t]{4}{*}{.001} \\
\hline & Negative & 25 & 3.48 & 140 & 15.73 & & & \\
\hline & Positive & 676 & 94.15 & 701 & 78.76 & & & \\
\hline & Neutral & 17 & 2.37 & 49 & 5.51 & & & \\
\hline
\end{tabular}

df degrees of freedom; cell freq. cell frequency

significantly more frequently as of higher social class, and less frequently as of lower social class, than females) was therefore not confirmed.

Race

There was overall significance across race; lower order categories $\chi^{2}(5, \mathrm{n}=1,615)=17.20, \mathrm{p}<.01$ and higher order categories $\chi^{2}(2, \mathrm{n}=1,615)=12.20, \mathrm{p}<.01$. Males were

represented proportionally less often as White $(61.75 \%, n=549)$, and more frequently as Black $(36.78 \%, n=327)$, in comparison to females (69.01\%, $\mathrm{n}=501$ and $30.58 \%, \mathrm{n}=222$ respectively). Both males and females were repre- sented proportionally more frequently as White than Black. H8 (i.e., Males will be represented significantly more frequently as members of the White population group, and less frequently as members of the Black population group, than females) was as a result unsupported. 
Table 3 Percentage and frequency of actors in advertisements

\begin{tabular}{|c|c|c|c|c|c|}
\hline Variable number & Category & Frequency & Cumulative frequency & Percent & Cumulative percent \\
\hline \multirow[t]{10}{*}{ v4. } & Actors & & & & \\
\hline & Male adult(s) & 378 & 378 & 13.10 & 13.10 \\
\hline & Female adult(s) & 381 & 759 & 13.21 & 26.31 \\
\hline & Child(ren) & 63 & 822 & 2.18 & 28.49 \\
\hline & Female and male adults & 824 & 1,646 & 28.56 & 57.05 \\
\hline & Male adult(s) with child(ren) & 93 & 1,739 & 3.22 & 60.28 \\
\hline & Female adult(s) with child(ren) & 131 & 1,870 & 4.54 & 64.82 \\
\hline & Female and male adults with child(ren) & 430 & 2,300 & 14.90 & 79.72 \\
\hline & None & 585 & 2,885 & 20.28 & 100.00 \\
\hline & Missing & 0 & 2,885 & .00 & 100.00 \\
\hline
\end{tabular}


Portrayal

An overall significant difference was found for portrayal; $\chi^{2}(2, n=1,608)=78.62, p<.001$. Females were proportion- ally more often represented positively $(94.15 \%, n=676)$, and proportionally less frequently represented negatively $(3.48 \%, n=$ $25)$, in comparison to males $(78.76 \%, n=701$ and $15.73 \%, n=140$ respectively). H9 (i.e., Males will be portrayed significantly more positively and less negatively than females) was therefore not confirmed.

\section{Discussion}

Content analyses should be embedded within a clear cultural context and theoretical framework (Furnham and Paltzer 2010). SA's unique cultural context, characterised by acute inequalities across, for example, gender and race, has been described. Social constructionism has also been argued to offer a worthwhile theoretical framework for the current study.

Social constructionism differs from gender role theory which, as already noted, has dominated empirical mass communication research for more than four decades. Research adopting the gender role perspective is motivated by what Wilkinson (2001, p. 18) calls feminist positivist empiricism. Here femininity and masculinity exist as fact, waiting to be observed, described and explained (Fejes

1992). Content analyses of media contribute toward their description as fact. Alternatively, this study is motivated by feminist social constructionism. This takes "the view that

'facts' are always dependent on the particular forms of language and the particular language communities which have created and maintained them". Therefore "we cannot

'know' the external world... or the internal world because all knowledge is mediated by-indeed, constructed through — the specificities of language" (Wilkinson 2001, p. 24). From this perspective femininity and masculinity do not exist as fact, waiting to be observed, described and explained. Rather they are considered social categories that are constantly (re)negotiated and variably understood. Content analyses of media merely contribute toward the preliminary interpreta- tion of broad gender representations.

In adopting a social constructionist theoretical frame- work, a clear distinction must be made between processes of representation and practice. Available representations of masculinities and femininities are assumed to inform gender practice and visa versa. Media, such as television advertising, are argued to construct readily accessible representations, which are strategically drawn upon in the course of social interaction, in a fashion that maintains hierarchical gender relations. Above all, media are argued to act as a key cultural tool through which a particular version of gender achieves, as well as maintains domi- nance. This study considers how masculinity and femininity are broadly constructed, as well as the way in which they intersect with other important social categories, through television advertising in SA. In so doing, it provides a firmer and necessary foundation upon which the relation- ship between processes of media representation of gender and its practice may be examined in more depth. In recognising fluidity and multiplicity in gender representa- tion and practice, social constructionism informs a different research agenda in comparison to traditional gender role theory. Avenues for future research that contribute toward this research agenda by, for example, foregrounding interpretive processes, are noted below.

Findings overwhelmingly support hypotheses and are largely congruent with existing research in the field. Males were significantly more likely to appear as primary visual actors (H1) and narrators (H2) than females. This was the case even though females marginally outnumber males in the SA population (Statistics South Africa 2001). These findings replicate results that have emerged from similar empirical research (e.g., Furnham et al. 1997, 2000; Furnham and Bitar 1993; Furnham and Farragher 2000). They suggest that television in SA continues to under- represent females. This may perpetuate their devaluation, or at a minimum fail to challenge existing gender inequalities in society. It also arguably serves to reinforce male authority (Gill 2007).

Content depicting a traditional division of labour between the genders may also serve this function. Once again findings largely mirror those appearing within other studies (e.g., Furnham et al. 2000; Livingstone and Green 1986; Mwangi 1996, $n=105$, Kenya). Females are most commonly repre- sented in the private-domestic arena as opposed to males who most often occupy public-work spaces (Fejes 1992; van Zoonen 1994). In this study males appeared proportionally more often in settings away from home, and outdoors at home, whereas females appeared proportionally more frequently in settings that were indoors at home (H3). The finding that female adults appeared alone with children, marginally more often than male adults, contributes toward their representation as domestically bound (H4). So too do product associations. Females were 
proportionally more often associated with domestically oriented products such as clothing; domestic goods; food; and personal care. Alternatively, males were proportionally more frequently associated with products such as vehicles; electronics; services; and leisure (H5). Comparable gender-product associations have emerged in other studies (e.g., Furnham et al. 1997, 2000; Furnham and Bitar 1993; Furnham and Farragher 2000; Livingstone and Green 1986; Lovdal

1989, $n=353$, United States; Mwangi 1996). These gender-product associations are said to strengthen therepresentation of females as domestically tied and males as inhabiting spaces outside of the domestic arena (Furnham and Mak 1999).

The proportionally higher frequency with which females are associated with personal care products emphasises the importance placed on their looks and debatably contributes toward their sexualisation. Women's sexualisation in televi- sion advertising is well documented (e.g., Lin 1998, n=505, United States; Sullivan and O'Connor 1988, n=364, United States) across different media (Collins

2011) and is noted to have increased over the years (van Zoonen 1994). This is perhaps most obvious when considering age representation. Females appeared propor- tionally more often in younger adult age categories whereas males appeared proportionally more frequently in older adult age categories (H6). Previous studies have produced largely equivalent results (e.g., Furnham and Bitar 1993; Furnham and Farragher 2000; Furnham and Mak 1999). This finding also suggests that males are represented as occupying positions of greater social authority vis-à-vis females.

Advertisement content may also indirectly contribute toward the representation of females as sex objects. This was evident in two findings. The first of these concerned the intersection of gender and social class. Both males and females were represented proportionally more fre- quently as of upper than lower/working social class. But females were proportionally more often represented as of upper/middle social class, in comparison to males, and proportionally less frequently represented as of lower/ working social class (H7). The second of these was that females were proportionally more often represented positively, in comparison to males, and proportionally less frequently represented negatively (H9). Initially these findings appear to challenge the hypotheses. Yet it might be suggested that positive depictions of females, who are of upper/middle social class, avoid disrupting their broader sexualisation. Literature supports this interpretation concerning the close relationship between representations of upper/middle social class women and beauty (e.g., Kratz 1991; Lee 2009).

The finding that females were proportionally more frequently represented as White as compared to Black arguably serves two functions. This intersection of gender and race may act to normalise, legitimate and (re)produce hierarchical power relations between women in society. Moreover the greater proportional appearance of White females suggests that they, rather than Black females, are represented as the aesthetic ideal. This interpretation is congruent with existing literature. It has been observed that media tends to represent physical features, which are typically associated with White women, as more attractive than those of Black women (e.g., Reddick-Morgan 2004, Europe/United States; Rich and Cash 1993, n= 750, United States). As noted above, Coltrane and Messineo's (2000) content analysis of television advertising goes so far as to suggest that whilst White women are represented as sex objects, Black women are represented as inconsequential. The unexpected result that females were represented significantly more frequently as members of the White population group, and less frequently as members of the Black population group, than males (H8) may underscore the extent to which the intersection of gender and race is central to women's sexualisation. Future research might usefully explore the extent to which the SA media represents physical features that are typically associated with White females, as more attractive than those of Black females. In the case of content analyses, this would contribute toward Furnham and Paltzer's (2010) call for greater creativity in content category development.

The finding that males were proportionally more frequently represented as White as compared to Black also may act to normalise, legitimate and (re)produce hierarchical power relations between men in society. This finding has similarly emerged in other research (e.g., Coltrane and Messineo 2000; Milner 2007). An analogous argument could be made for the finding that males and females were represented proportionally more frequently as of upper than lower/working social class. That is to say, this may act to normalise, legitimate and (re)produce hierarchical power relations within and between men and women of different social classes in SA.

In sum, and at first glance, findings support the hypotheses that males and females are represented significantly differently in television advertisements, and the contention that these differences reflect traditional gender relations. Males are represented as dominant. They are of primary focus; appear most frequently within the socially valued public-work arena; and are repre- sented as occupying positions of greater social authority. Females are represented as subordinate. They are of secondary focus; appear most frequently within the socially undervalued private-domestic arena; and are most 
often represented as occupying positions of social subordination. This subordination is reinforced through findings that imply their sexualisation. Future content analytic research might fruitfully code for this represen- tation directly as suggested by Collins (2011).

It is important to underline the extent to which these headline results might serve to hide interesting patterns in the findings which speak to potential change in media representation of gender within SA and multiplicity in gender realities. Some of these patterns are highlighted below. They too indicate possible avenues for future research as is appropriate when adopting a social construc- tionist theoretical framework

\section{Conclusion}

Television advertising in SA represents males and females as existing in hierarchical relations with one another. Males are represented as dominant whereas as females are represented as subordinate. These represen- tations arguably mirror the inequitable distribution of economic, political and social power within SA. Recent political transformation may be challenging current gender representation but does not as of yet appear to have resulted in fundamental change in television advertising. This finding should inform media policy and programming debates in the country. Yet it should not be taken to mean that change has and is not occurring. Mager's (2010) recent work, for example, indicates changing gender representation in beer advertis- ing in SA. As noted above, the overall representation of males as dominant should also not obscure more surprising trends in the data. It is interesting, for instance, that although female adults appeared alone with children more often than male adults, this was only marginally so. Whilst this may certainly contribute toward their representation as domestically bound, we might ponder the interesting fact that men appeared with children so often. Similarly, men's association with domestic goods and personal care products is noteworthy, even though this is less than women. Interesting questions regarding changes in fatherhood, the structure of the family, and the definition of masculinities in relation to marketing strategies emerge as a result. In this respect it is worthwhile to remember that advertisements act as lagging indicators of social change (Eisend 2010; Gauntlett 2009) which in actuality may be far more dramatic.

A reciprocal relationship between representation and practice is theoretically argued to result in the maintenance of hierarchical gender relations. In SA this involves the (re)production of gender representations that appear to favour White, middle-class males. This similarly appears in studies conducted within Western countries (Fejes 1992). It contributes toward the preservation of social hierarchies, in particular, men's dominance over women. Findings largely point toward the stereotypical representation of gender in SA. Although interesting patterns emerge that suggest change, these are limited, and therefore findings lend some support for the notion that countries with lower socio- economic development are likely to exhibit more traditional gender representation. We should, nonetheless, remain mindful of contradictory findings offered by other research (e.g., Uray and Burnaz 2003; Furnham et al. 2000) as well as Furnham and Mak’s (1999) experience in drawing such conclusions. Cross-national comparisons are made difficult through channel equivalence; sampling equivalence across different time periods; and variation in meaningful content categories due to changes over time.

Craig (1992b, p. 198) notes that "(w)hile content analysis is limited in the information it can provide about television gender representations, it can and should provide the essential starting point for further critical analysis”-a view supported by Neuendorf (2011). Its limitations include an inability to describe subtle relationship between gender representation, practices and identities or to explore the complex connection between advertising and gender repre- sentation. This most notably increases the risk of reifying the binary categories of male and female. Nonetheless it is hoped that this study provides a useful starting point for future critical analysis. It offers a broad overview of current gender representation by the television media in SA. van Zoonen (1994) notes that content analyses are especially useful in contexts, such as developing countries, where general understanding of how men and women are represented is lacking. Other methodologies are better suited to exploring complexities in gender representations, practices and identities [e.g., discursive psychology (Potter and Wetherell 2005)] or advertising and gender representa- tion [e.g., audience interpretation research (Livingstone

1990)]. In the latter case it is essential to consider how communication content emerges as a result of antecedent conditions as well as its effect. Manstead and McCulloch (1981) underline the obvious difficulty in determining effect through traditional experimental methodologies: it is virtually impossible to obtain a control group who have not been exposed to television advertising. Novel research should be devised to address this issue; especially those that suitably account for interpretive processes. Collins (2011) argues that such future research might best be achieved through interdisciplinary collaboration. Lastly, it is fair to suggest that gender relations are changing rapidly in SA due to its dynamic socio-political milieu, shifting media consumption patterns (Strelitz 2002), and broader global- ising processes (Salo 2003). This study therefore 
also offers a foundation for mapping changes in gender representation within television advertising through future longitudinal research.

Acknowledgement Research funds were made available through the Commonwealth Commission and Universities UK. Special thanks go to Hayley Nichols and Jenny Luyt for their research assistance as well as the reviewers for their helpful suggestions.

\section{References}

Arima, A. N. (2003). Gender stereotypes in Japanese television advertisements. Sex Roles, 49, 81-90. doi:10.1023/ A:1023965704387.

Bauer, M. W. (2000). Classical content analysis: A review. In M. W.

Bauer \& G. Gaskell (Eds.), Qualitative researching: With text image and sound (pp. 131-151). London: Sage. Berg, B. L. (1998).

Qualitative research methods for the social sciences. Boston: Allyn and Bacon.

Bohan, J. S. (1993). Regarding gender: Essentialism, constructionism, and feminist psychology. Psychology of Women Quarterly, 17, 521. doi:10.1111/j.1471-6402.1993.tb00673.x.

Bresnahan, M. J., Inoue, Y., Liu, W. Y., \& Nishida, T. (2001). Changing gender roles in prime-time commercials in Malaysia, Japan, Taiwan, and the United States. Sex Roles, 45, 117-131. doi:10.1023/A:1013068519583.

Burr, V. (2003). Social constructionism. London: Routledge.

Collins, R. L. (2011). Content analysis of gender roles in media: Where are we now and where should we go? Sex Roles, 64, 290298. doi:10.1007/s11199-010-9929-5.

Coltrane, S., \& Messineo, M. (2000). The perpetuation of subtle prejudice: Race and gender imagery in 1990s television adver- tising. Sex Roles, 42, 363-389. doi:10.1023/A:1007046204478.

Connell, R. W. (2000). The men and the boys. Cambridge: Polity.

Craig, R. S. (1992a). The effect of television day part on gender portrayals in television commercials: A content analysis. Sex Roles, 26, 197211. doi:10.1007/BF00289707.

Craig, R. S. (1992b). Considering men and the media. In R. S. Craig

(Ed.), Men, masculinity and the media (pp. 1-7). Newbury Park: Sage.

de Villiers, C. (1998). Qualified parental rights for unmarried fathers.

Agenda, 37, 82-85. doi:10.1080/10130950.1998.9675697. Dominick, J., \& Rauch, G. (1972). The image of women in network

TV commercials. Journal of Broadcasting, 16, 259-266. DuRant, R. H., Rome, E. S., Rich, M., Allred, E., Emans, S. J., \&

Woods, E. R. (1997). Tobacco and alcohol use behaviors portrayed in music videos: A content analysis. American Journal of Public Health, 87, 1131-1135.

Eisend, M. (2010). A meta-analysis of gender roles in advertising. Journal of the Academy of Marketing Science, 38, 418-440. doi:10.1007/s11747-009-0181-x.

Fejes, F. J. (1992). Masculinity as fact: A review of empirical mass communication research on masculinity. In R. S. Craig (Ed.), Men, masculinity and the media (pp. 9-22). Newbury Park: Sage.

Furnham, A., \& Bitar, N. (1993). The stereotyped portrayal of men and women in British television advertisements. Sex Roles, 29, 297-310. doi:10.1007/BF00289940.

Furnham, A., \& Chan, F. (2003). The gender-role stereotyping of men and women in Hong Kong television advertisements. Psycholo- gia, 46, 213-224. doi:10.2117/psysoc.2003.213.

Furnham, A., \& Farragher, E. (2000). A cross-cultural content analysis of sex-role stereotyping in television advertisements: A compar-ison between Great Britain and New Zealand. Journal of Broadcasting and Electronic Media, 44, 415-436. doi:10.1207/ s15506878jobem4403_5.

Furnham, A., \& Mak, T. (1999). Sex-role stereotyping in television commercials: A review and comparison of fourteen studies done on five continents over 25 years. Sex Roles, 41, 413-437. doi:10.1023/A:1018826900972.

Furnham, A., \& Paltzer, S. (2010). The portrayal of men and women in television advertisements: An updated review of 30 studies published since 2000. Scandinavian Journal of Psychology, 51, 216-236. doi:10.1111/j.1467-9450.2009.00772.x.

Furnham, A., \& Skae, E. (1997). Changes in the stereotypical portrayal of men and women in British television advertisements. European Psychologist, 2, 44-51. doi:10.1027/1016-9040.2.1.44. Furnham, A., \& Spencer-Bowdage, S. (2002). Sex role stereotyping in television from South Africa and Great Britain. Communications, 27, 457483. doi:10.1515/comm.2002.003,19/11/2002.

Furnham, A., Abramsky, S., \& Gunter, B. (1997). A cross-cultural content analysis of children’s television advertisements. Sex Roles, 37, 91-99. doi:10.1023/A:1025692804434.

Furnham, A., Mak, T., \& Tanidjojo, L. (2000). An Asian perspective on the portrayal of men and women in television advertisements: Studies from Hong Kong and Indonesian television. Journal of Applied Social Psychology, 30, 2341-2364. doi:10.1111/j.1559-

1816.2000.tb02440.x.

Gaitskell, D., Kimble, J., Maconachie, M., \& Unterhalter, E. (2010). 
Domestic workers in South Africa: Class, race and gender. In M. Turshen (Ed.), African women: A political economy (pp. 35-52). Basingstoke: Palgrave Macmillan.

Ganahl, D. J., Prinsen, T. J., \& Netzley, S. B. (2003). A content analysis of prime time commercials: A contextual framework of gender representation. Sex Roles, 49, 545-551. doi:10.1023/ A:1025893025658.

Gauntlett, D. (2009). Media, gender and identity: An introduction. London: Routledge.

Gerbner, G., \& Gross, L. (1976). Living with television: The violence profile. Journal of Communication, 26, 172-199. doi:10.1111/ j.14602466.1976.tb01397.x.

Gergen, K. (1999). An invitation to social construction. London: Sage.

Gill, R. (2007). Gender and the media. Cambridge: Polity.

Glascock, J., \& Ruggiero, T. E. (2004). Representations of class and gender on primetime Spanish-language television in the United States. Communication Quarterly, 52, 390-402. doi:10.1080/ 01463370409370208.

Gunnarsson, B. L. (1997). On the socio-historical construction of scientific discourse. In B. L. Gunnarsson, P. Linell, \& B. Nordberg (Eds.), The construction of professional discourse (pp. 99-126). London: Longman.

Haberman, S. J. (1988). A warning on the use of chi-square statistics with frequency tables with small expected cell counts. Journal of the American Statistical Association, 83, $555-560$.

Hanke, R. (1992). Redesigning men: Hegemonic masculinity in transition. In R. S. Craig (Ed.), Men, masculinity and the media (pp. 185-198). Newbury Park: Sage.

Joffe, H., \& Yardley, L. (2003). Content and thematic analysis. In D. F. Marks \& L. Yardley (Eds.), Research methods for clinical and health psychology (pp. 56-88). London: Sage.

Kalichman, S. C., Simbayi, L. C., Kaufman, M., Cain, D., Cherry, C., Jooste, S., et al. (2005). Gender attitudes, sexual violence, and HIV/AIDS risks among men and women in Cape Town, South Africa. Journal of Sex Research, 42, 299-305. doi:10.1080/ 00224490509552285.

Kim, K., \& Lowry, D. T. (2005). Television commercials as a lagging social indicator: Gender role stereotypes in Korean television advertising. Sex Roles, 53, 901-910. doi:10.1007/s11199-0058307-1.

Kratz, S. L. (1991). Manufacturing the gentleman's girl: Beauty, class, and the adult entertainment club (Master's thesis). Available from DigitalCommons@Florida Atlantic University.

Lauzen, M. M., \& Dozier, D. M. (2005). Maintaining the double standard: Portrayals of age and gender in popular films. Sex Roles, 52, 437446. doi:10.1007/s11199-005-3710-1.

Lee, C. W. (2004). Gender role stereotyping in television commercials: The case of Singapore. Advertising \& Society Review, 5. Retrieved from http://muse.jhu.edu/journals/asr/v005/5.3lee.html

Lee, N. (2009). Women's discourse on beauty and class in the Bolivarian Republic of Venezuela. Culture \& Psychology, 15, 147-167. doi:10.1177/1354067X08099619.

Levett, A., \& Kottler, A. (1998). Through a lens, darkly. In E. Burman (Ed.), Deconstructing feminist psychology (pp. 184-205). Thou- sand Oaks: Sage.

Lin, C. A. (1998). Uses of sex appeals in prime-time television commercials. Sex Roles, 38, 461-475. doi:10.1023/ A:1018714006829

Livingstone, S. M. (1990). Making sense of television: The psychology of audience interpretation. Oxford: Butterworth Heinemann.

Livingstone, S., \& Green, G. (1986). Television advertisements and the portrayal of gender. British Journal of Social Psychology, 25, 149-154. doi:10.1111/j.2044-8309.1986.tb00713.x.

Lovdal, L. T. (1989). Sex role messages in television commercials: An update. Sex Roles, 21, 715-724. doi:10.1007/BF00289804.

Luyt, R. (2003). Rhetorical representations of masculinities in South Africa: Moving towards a material-discursive understanding of men. Journal of Community and Applied Social Psychology, 13, 46-69. doi:10.1002/casp.706.

Luyt, R. (2005). The Male Attitude Norms Inventory-II: A measure of masculinity ideology in South Africa. Men \& Masculinities, 8, 208-229. doi:10.1177/1097184X04264631.

Bloomington: Indiana University Press.

Manstead, A. S. R., \& McCulloch, C. (1981). Sex-role stereotyping in British television advertisements. British Journal of Social Psychology, 20, 171-180. doi:10.1111/j.2044-8309.1981. tb00529.x.

McArthur, L. Z., \& Resko, B. G. (1975). The portrayal of men and women in American television commercials. Journal of Social

Psychology, 97, 209-220. doi:10.1080/00224545.1975.9923340. Milner, L. M. (2005). Sex-role portrayals in African television advertising. 73-91. doi:10.1300/J046v17n02_05.

Africa television advertisements. Journal of African Business, 8, 41-59. doi:10.1300/J156v08n02_04.

Moon, Y. S., \& Chan, K. (2002). Gender portrayal in Hong Kong and Korean children’s TV commercials: A cross-cultural comparison. Asian Journal of Communication, 12, 100-119. doi:10.1080/ 01292980209364825.

Morrell, R. (1998). Of boys and men: Masculinity and gender in Southern African studies. Journal of Southern African Studies, 
24, 605-630. doi:10.1080/03057079808708593.

Morrell, R. (2001). The times of change: Men and masculinity in South Africa. In R. Morrell (Ed.), Changing men in Southern Africa (pp. 3-37). Pietermaritzburg: University of Natal Press.

Morrell, R. (2002). Men, movements, and gender transformation in South Africa. The Journal of Men's Studies, 10, 309-327. doi:10.3149/jms.1003.309.

Mwangi, M. W. (1996). Gender roles portrayed in Kenyan television commercials. Sex Roles, 34, 205-214. doi:10.1007/BF01544296. Neuendorf, K. A. (2011). Content analysis: A methodological primer for gender research. Sex Roles, 64, 276-289. doi:10.1007/s11199010-9893-0.

Oyegun, J. (1998). Working masculinities back into gender. Agenda, 37, 60-64. doi:10.1080/10130950.1998.9675684.

Pelak, C. F. (2005). Negotiating gender/race/class constraints in the new South Africa: A case study of women's soccer. International Review for the Sociology of Sport, 40, 53-70. doi:10.1177/1012690205052165.

Potter, J., \& Wetherell, M. (2005). Discourse and social psychology: Beyond attitudes and behaviour. London: Sage.

Reddick-Morgan, K. A. (2004). Emulated through images: The globalization of misconstructed African American beauty and hip-hop culture. Globalization. Retrieved from http://globaliza tion.icaap.org/content/v4.1/reddick-morgan.html.

Reddy, V. (1998). Negotiating gay masculinities. Agenda, 37, 65-70. doi:10.1080/10130950.1998.9675693.

Reddy, S., \& Dunne, M. (2007). Risking it: Young heterosexual femininities in South African context of HIV/AIDS. Sexualities, 10, 159-172. doi:10.1177/1363460707075797.

Rich, M. K., \& Cash, T. F. (1993). The American image of beauty: Media representations of hair color for four decades. Sex Roles, 29, 113-124. doi:10.1007/BF00289999.

Riffe, D., Lacy, S., \& Fico, F. G. (1998). Analyzing media messages: Using quantitative content analysis in research. Mahwah: Erlbaum.

Salo, E. (2003). Negotiating gender and personhood in the new South Africa: Adolescent women and gangsters in Manenberg township on the Cape Flats. European Journal of Cultural Studies, 6, 345365. doi:10.1177/13675494030063005.

Seekings, J., \& Nattrass, N. (2006). Class, race, and inequality in South Africa. New Haven: Yale University Press.

Shefer, T., Crawford, M., Strebel, A., Simbayi, L. C., Dwadwa-Henda, N., Cloete, A., et al. (2008). Gender, power and resistance to change among two communities in the Western Cape, South Africa. Feminism \& Psychology, 18, 157-182. doi:10.1177/ 0959353507088265.

Statistics South Africa. (2001). Census 2001: Census in Brief. Pretoria: Statistics South Africa.

Statistics South Africa. (2003). Census 2001: Census in brief. Pretoria: Statistics South Africa.

Strelitz, L. N. (2002). Media consumption and identity formation: The case of the 'homeland' viewers. Media Culture Society, 24, 459480. doi:10.1177/016344370202400401.

Sullivan, G. L., \& O’Connor, P. J. (1988). Women’s role portrayals in magazine advertising: 1958-1983. Sex Roles, 18, 181-188. doi:10.1007/BF00287788.

Terreblanche, S. (2003). A history of inequality in South Africa 1652-2002. Pietermaritzburg: University of KwaZulu-Natal Press.

United Nations Development Programme. (2009). Human development report 2009. Basingstoke: Palgrave Macmillan.

Uray, N., \& Burnaz, S. (2003). An analysis of the portrayal of gender roles in Turkish television advertisements. Sex Roles, 48 , $77-87$. doi:10.1023/A:1022348813469.

van Zoonen, L. (1994). Feminist media studies. London: Sage.

Weber, R. P. (1990). Basic content analysis. Newbury Park: Sage. West, C., \& Zimmerman, D. H. (1991). Doing gender. In J. Lorber \& S. A. Farrell (Eds.), The social construction of gender (pp. 1337). Newbury Park: Sage.

Wilkinson, S. (2001). Theoretical perspectives on women and gender. In R. K. Unger (Ed.), Handbook of the psychology of women and gender (pp. 17-28). Hoboken: Wiley. 